\title{
Impacts of Magnetic Field Treatment on Water Quality for Irrigation, Soil Properties and Maize Yield
}

\author{
A. H. Hamza ${ }^{1^{*}}$, M. A. Sherif ${ }^{1}$, Wael Abdelmoez ${ }^{2}$ and M. M. Abd El-Azeim ${ }^{1}$ \\ ${ }^{1}$ Department of Soil Sciences, Faculty of Agriculture, Minia University, Egypt \\ ${ }^{2}$ Department of Chemical Engineering, Faculty of Engineering, Minia University, Egypt \\ * Correspondence: ahmed.gaber@mu.edu.eg DOI: 10.21608/jmr.2020.44778.1053.
}

\section{Article information}

Received: 5 October 2020

Revised: 11 October 2020

Accepted: 17 October 2020

\section{Key words}

Magnetized water

Water scarcity

Soil salinity

\begin{abstract}
Application of magnetic treatment technology for saline irrigation water in agriculture is very limited. Therefore, field experiment was conducted to investigate the influence of magnetic field treatment on the quality of saline groundwater for irrigation and in turn impacts of irrigation by magnetized water on sandy soil properties and maize production under desert conditions in Sinai, Egypt. Magnetic field treatment of irrigation water caused leaching salts below root zones, reduced sodium and chloride accumulation, decreased $\mathrm{Na} / \mathrm{Cl}$ ratio from 1.01 to 0.89 which mitigated the negative impacts on maize plants in the root zone. Results showed high significant decreases in soil salinity (EC, and SAR) and levels of soil soluble cations and anions in the root zone of soils irrigated with magnetically treated saline water compared to control. Also, sandy soil irrigated with magnetized water had a higher moisture content, available water and soil field capacity compared to control. Irrigation with unmagnetized water induced wetted soil volume of $2575.68 \mathrm{~cm}^{3}$ reflecting low drip irrigation application efficiency of $64.07 \%$, while wetted soil volume was $2919.24 \mathrm{~cm}^{3}$ reflecting high water application efficiency of $72.62 \%$ for irrigation with magnetized water. Results of this research demonstrated significant beneficial effects of magnetic field treatment on saline water quality, sandy soil properties and maize crop yield confirming the possibility of using low quality water for irrigation under water scarcity and arid conditions.
\end{abstract}

\section{Introduction}

The agricultural production worldwide is one of the most basic elements contribute to the economic income and food security, yet it faces many problems accompanied with it such as lack of water, desertification, salinity and low yield. Moreover, food production must increase to meet the needs of an ever-increasing population which goes beyond mandates that soil quality be restored and enhanced [1].

Irrigated agriculture is the largest consumer of water in the world. In areas with dry climate, irrigation water amount to $85 \%$ of total water use [2].

In Egypt, under the population pressure, the need to provide additional lands for farming in order to increase food production to cope with the acceleration of population growth compels the country to use all sources of low-quality water [2]. High contents of soluble salts accumulated in the soil can significantly decrease the value and productivity of agricultural lands. Using poor quality irrigation water with high salinity is one of the main problems in agriculture of many countries in the world [3].

The use of saline water for agricultural production in water scarcity regions requires innovative and sustainable research and appropriate technical methods. Maize (Zea mays), also called corn, is believed to have originated in central Mexico
7000 years ago from a wild grass, and Native Americans transformed maize into a better source of food. Maize contains approximately $72 \%$ starch, $10 \%$ protein, and $4 \%$ fat, supplying an energy density of $365 \mathrm{Kcal} / 100 \mathrm{~g}$ and is grown throughout the world, with the United States, China, and Brazil being the top three maize-producing countries, producing approximately 563 of the 717 million metric tons/year. Maize can be processed into a variety of food and industrial products, including starch, sweeteners, oil, beverages, glue, industrial alcohol, and fuel ethanol. In the last 10 years, the use of maize for fuel production significantly increased, accounting for approximately $40 \%$ of the maize production in the United States. As the ethanol industry absorbs a larger share of the maize crop, higher prices for maize will intensify demand competition and could affect maize prices for animal and human consumption. Low production costs, along with the high consumption of maize flour and cornmeal, especially where micronutrient deficiencies are common public health problems, make this food staple an ideal food vehicle for fortification.

In fact, constant usage of saline or brackish water for crop production boosts soil salinity [4].

These problems can be remedied, partially, using a technique of magnetic treatment of water. This technique has become the focus of researchers as it ensures clear environment, health conditions, and easy handling. Accumulated contents of 
soluble salts in the soil and root zone can significantly diminish the crop value and productivity of agricultural soils. Impacts of a magnetic field on several plant growth processes like seed germination, seedling growth, yield and crop quality attributes have been the item of much research [3] and [4].

In Egypt, there is relatively little studies on magnetized water and the application of magnetized water in agriculture is very limited due to some researchers still refute and underestimate its effects upon water and soil productivity. Consequently, the present work aimed to study the effects of magnetic pretreatment of groundwater used for irrigation on the productivity of irrigation water, soil and maize crop yield and its application for sustainable agricultural practices under desert sandy soils conditions using drip irrigation system.

\section{Materials and Methods}

Experiment was conducted at the experimental facilities of the Agricultural Research Center, (latitudes $27^{\circ} 45^{\prime} \mathrm{N}$ and $31^{\circ} 30^{\prime}$ $\mathrm{N}$ and longitudes $32^{\circ} 00^{\prime} \mathrm{E}$ and $35^{\circ} 00^{\prime} \mathrm{E}$ ) Sinai Regional Center for Horticultural crops in Sinai Governorate, Egypt, during the agricultural season 2017. This study was carried out using randomized complete block design (the tow-way ANOVA) consisted of 24 plots with three replicates. The experimental design included two factors, the first was irrigation water including magnetized and unmagnetized and the second factor was involved drip irrigation at different distances i.e., 100, 200and 300-meters distance. The magnetic field treatment was applied using AQUA-PHYD treatment device provided by OAKWOODE company with a capacity range of one $\mathrm{T}$ (Tesla).

The experimental field was drip irrigated from magnetized and unmagnetized well waters which were slightly different in their salinities. Drip irrigation network consisted of control head, pump, filtration unit, back flow prevention device, pressure regulator, and control valves and it was driven by diesel engine. The main line of the irrigation network was PVC tube with 6-inch diameter, while, the lateral lines of irrigation network were PVC tubes with 3-inch diameter and dripper line $16 \mathrm{~mm}$ drip lateral line contained one hundred GR-type emitters at $50 \mathrm{~cm}$ spacing with the water discharge at $4 \mathrm{Lh}^{-1}$ every irrigation.

\subsection{Study area and aquifer geological settings in Sinai.}

The Egyptian Sinai Peninsula has land area of about $61,000 \mathrm{~km} 2$ representing about $6 \%$ of Egypt's area and lies in the arid to hyper-arid belt of North Africa and belongs to the Saharan-Mediterranean climate region. Most of Sinai Peninsula (excluding the mountains) is classified as extremely arid (P/EP< $0.03)$, where $\mathrm{P}$ is the annual precipitation and EP is the potential evapotranspiration [5].

The average temperatures range from $18^{\circ} \mathrm{C}$ to $31^{\circ} \mathrm{C}$ in summer and from $7^{\circ} \mathrm{C}$ to $21^{\circ} \mathrm{C}$ in winter [6].

The mean annual rainfall for Sinai is about $40 \mathrm{~mm} /$ year, of which an estimated $60 \%$ is lost to evapotranspiration, $5 \%$ runoff to the sea, and $35 \%$ infiltrates deep into the rocks and unconsolidated deposits; much of which constitutes groundwater recharge [6].

\subsection{Experimental procedures and treatments.}

Soil of the experimental field was refined and prepared for maize cultivation. Before the experiment, soil was perpendicularly plowed twice, then underwent the process of smoothing and leveling and divided into four lines along each line of $27 \mathrm{~m}$. Phosphorus fertilization was applied to soil plots in the form of calcium superphosphate $(15.5 \%$ P2O5) at the standard recommended rate by the Ministry of Agriculture, Egypt, during the soil preparation. Nitrogen fertilization was applied to soils as ammonium nitrate $(33.5 \% \mathrm{~N})$ at the standard recommended rate in three doses starting one month after sowing. The recommended levels of potassium fertilization were applied as potassium sulphate $(48 \% \mathrm{~K} 2 \mathrm{O})$ in three doses starting one month after sowing. All the agricultural practices except irrigation with magnetized water and different irrigation distances were applied as commonly used for growing maize in the desert agriculture.

Corn seeds var. hybrid Bashayer obtained from the Agricultural Research Centre were planted in early March and harvested in late August. Three corn seeds were implanted in each hole, $0.25 \mathrm{~m}$ between holes and $0.75 \mathrm{~m}$ distance between lines. After germination, corn plants were thinned to one plant and weeds were removed manually three times during the season.

At maize maturity and harvest, four plants from each plot middle lines were collected at random and examined for maize growth and yield characteristics.

After maize harvesting, the soil of the experimental field was collected and characterized in order to monitor the soil salinity build up and to observe the changes in some soil chemical and physical properties.

\subsection{Soil analyses and characteristics.}

Soil samples were collected from soil surface at $0.0-60 \mathrm{~cm}$ depth of each plot by excavating soil pits before and after maize cultivation. Soil samples were air dried, crushed, and sieved to pass through a $2.0 \mathrm{~mm}$ stainless steel sieve. Sieved soil samples were mixed thoroughly, and a subsample was taken for soil analyses using standard methods as described by [7].

Some physicochemical properties of the investigated soil characterized as (Entisol-Typic Torripsamments) before maize cultivation are illustrated in Table (1).

\subsection{Groundwater quality analyses and characteristics.}

Prior to maize cultivation, water samples of magnetized and unmagnetized groundwater available for irrigation was collected and analyzed to evaluate its suitability for irrigating maize plants and to predict their effects on some physicochemical properties of the sandy soil investigated. At each irrigation event, water samples were collected in a clean 
and dried plastic bottle, filtered and stored at $4.0{ }^{\circ} \mathrm{C}$ until analysis, which was performed immediately, or preserved in accordance with American Public Health Association [8].

Table 1. Soil physicochemical properties of Saini experimental site.

\begin{tabular}{|c|c|c|c|c|}
\hline \multirow{2}{*}{\multicolumn{2}{|c|}{ Particles Size Distribution (\%) }} & \multicolumn{3}{|c|}{$\begin{array}{l}\text { Depth Before Treated Water } \\
(\mathbf{c m})\end{array}$} \\
\hline & & 0 - 20 & $20-40$ & $40-60$ \\
\hline \multicolumn{2}{|c|}{ Coarse Sand \% } & 35.05 & 41.79 & 40.88 \\
\hline \multicolumn{2}{|c|}{ Medium Sand \% } & 22.93 & 24.42 & 23.15 \\
\hline \multicolumn{2}{|c|}{ Fine Sand \% } & 34.44 & 29.29 & 32.67 \\
\hline \multicolumn{2}{|c|}{ Silt + Clay \% } & 7.58 & 4.50 & 3.30 \\
\hline \multicolumn{2}{|c|}{ Soil Texture } & Sand & Sand & Sand \\
\hline \multicolumn{2}{|c|}{ Field Capacity \% } & 10.64 & 10.55 & 10.46 \\
\hline \multicolumn{2}{|c|}{ Wilting Point \% } & 3.54 & 3.65 & 3.58 \\
\hline \multicolumn{2}{|c|}{ Available Water } & 7.10 & 6.90 & 6.88 \\
\hline \multicolumn{2}{|c|}{ Bulk Density $\left(\mathrm{g} \mathrm{cm}^{-3}\right)$} & 1.58 & 1.53 & 1.57 \\
\hline \multicolumn{5}{|c|}{ Soil Chemical Properties: } \\
\hline \multicolumn{2}{|c|}{ pH (1:2.5) } & 8.16 & 8.11 & 8.22 \\
\hline \multicolumn{2}{|c|}{$\operatorname{EC~}(1: 2.5)\left(\mathrm{dS} \mathrm{m}^{-1}\right)$} & 3.20 & 3.24 & 3.15 \\
\hline \multicolumn{2}{|c|}{$\mathrm{CaCO}_{3} \mathrm{~g} \mathrm{~kg}^{-1}$} & 29.15 & 27.19 & 22.33 \\
\hline \multirow{3}{*}{$\begin{array}{c}\text { Soluble } \\
\text { Anions } \\
\left(\mathbf{m m o l}_{\mathbf{c}} \mathbf{L}^{-1}\right)\end{array}$} & $\left(\mathrm{HCO}^{3-}+\mathrm{CO}_{3}{ }^{2-}\right)$ & 7.72 & 7.83 & 7.56 \\
\hline & $\mathbf{C L}^{-}$ & 12.31 & 12.15 & 12.28 \\
\hline & $\mathrm{SO}_{4}{ }^{2-}$ & 11.62 & 11.15 & 11.53 \\
\hline \multirow{4}{*}{$\begin{array}{c}\text { Soluble } \\
\text { Cations } \\
\left(\text { mmol }_{\mathbf{c}} \mathbf{L}^{-1}\right)\end{array}$} & $\mathrm{Ca}^{2+}$ & 9.35 & 9.46 & 9.61 \\
\hline & $\mathbf{K}^{+}$ & 0.23 & 0.18 & 0.16 \\
\hline & $\mathrm{Mg}^{2+}$ & 3.42 & 3.48 & 3.62 \\
\hline & $\mathrm{Na}^{+}$ & 18.80 & 18.62 & 18.53 \\
\hline \multicolumn{2}{|c|}{$\begin{array}{c}\text { Sodium Adsorption Ration } \\
\text { (SAR) }\end{array}$} & 7.44 & 7.33 & 7.20 \\
\hline
\end{tabular}

The chemical composition and criteria of magnetized and unmagnetized well water samples are presented in Table (2).

Table 2. Chemical composition and criteria of irrigation water in Saini experimental site

\begin{tabular}{|c|c|c|}
\hline \multicolumn{2}{|c|}{ Water Chemical Properties: } & Value \\
\hline \multicolumn{2}{|c|}{ pH } & 7.88 \\
\hline \multicolumn{2}{|c|}{$E C\left(d S ~ m^{-1}\right)$} & 6.81 \\
\hline \multirow{3}{*}{$\begin{array}{l}\text { Soluble Anions } \\
\left(\text { mmolc } \mathbf{L}^{-1}\right)\end{array}$} & $\left(\mathrm{HCO}_{3}{ }^{-}+\mathrm{CO}_{3}{ }^{2-}\right)$ & 5.13 \\
\hline & $\mathbf{C L}^{-}$ & 41.07 \\
\hline & $\mathrm{SO}_{4}{ }^{2-}$ & 10.48 \\
\hline \multirow{4}{*}{$\begin{array}{l}\text { Soluble Cations } \\
\quad\left(\text { mmolc } \mathbf{L}^{-1}\right)\end{array}$} & $\mathrm{Ca}^{2+}$ & 8.22 \\
\hline & $\mathbf{K}^{+}$ & 0.21 \\
\hline & $\mathbf{M g}^{2+}$ & 7.54 \\
\hline & $\mathrm{Na}^{+}$ & 40.81 \\
\hline \multicolumn{3}{|c|}{ Chemical criteria: } \\
\hline \multicolumn{2}{|c|}{ Sodium Adsorption Ration } & 14.52 \\
\hline \multicolumn{2}{|c|}{$\mathrm{Ca}^{2+} / \mathrm{Mg}^{2+}$ Ratio } & 1.09 \\
\hline \multicolumn{2}{|c|}{ Magnesium Hazard (M.H\%) } & 47.84 \\
\hline \multicolumn{2}{|c|}{$\mathrm{Na}^{+} / \mathrm{Cl}^{-}$Ratio } & 1.01 \\
\hline \multicolumn{2}{|c|}{ Sodium percentage $(\mathrm{Na} \%)$} & 72.24 \\
\hline \multicolumn{2}{|c|}{ Permeability index $(\%)$} & 75.43 \\
\hline
\end{tabular}

\subsection{General analytical determination and analyses}

Details of analytical analyses implemented during the course of both experiments were as following:

\subsubsection{Estimation of soil moisture distribution}

According to [9], method of specifying soil moisture. Contour maps for spatial distributions of moisture levels with different depths were performed by using Surfer Software (Golden Software, Inc., Golden, CO).

\subsubsection{Determination of water use efficiency}

The water that utilized in the season calculated by the discharge emitter in the time of irrigation ( 2 hours) on the day (the irrigation was day after day) and the value of water is multiplied by number of irrigation days. According to [10].

\subsubsection{Determination of fertilizer use efficiency}

According to [11], fertilizer use efficiency "FUE" was determined for the tested NPK.

\subsubsection{Sodium Adsorption Ratio (SAR).}

Sodium Adsorption Ratio (SAR) is calculated according to [12].

\subsubsection{Magnesium Hazard percentage.}

Magnesium hazard values can be calculated according to $[13]$

\subsubsection{Permeability Index}

The Permeability Index is calculated according to [14].

\subsubsection{Sodium Percentage}

The percentage of sodium (\% $\mathrm{Na}$ ) is also commonly utilized for assessing the suitability of water quality for irrigation and calculated using the following formula [15].

\subsection{Statistical analysis.}

The obtained results of both experiments were subjected to analysis of variance using the least significant difference (L.S.D.) test at 5\% level of probability using the MSTAT-C v. 1.42. Significance of the differences was estimated and compared using Duncan test at 5\% level of probability $(\mathrm{p}<0.05)$.

\section{3- Results and discussion}

This research aimed to evaluate impacts of magnetized and unmagnetized irrigation groundwater on the growth and yield components of maize crop under desert sandy soil conditions using drip irrigation system with different irrigation distances. In particular, results are presented under these main headings i.e., effects of magnetic field treatment on irrigation groundwater quality, water and fertilizer use efficiency and maize crop productivity and sandy soil properties. 


\subsection{Effects of magnetic field treatment on groundwater quality.}

Irrigation water quality was assessed mainly by $\mathrm{pH}$, soluble salt content (EC), main soluble anions and cations, sodium adsorption ratio (SAR), $\mathrm{Ca}^{2+} / \mathrm{Mg}^{2+}$ Ratio, Magnesium Hazard ( $\mathrm{MH} \%$ ), $\mathrm{Na}^{+} / \mathrm{Cl}^{-}$Ratio, Sodium percentage $(\mathrm{Na} \%)$ and permeability index $(\%)$. Results on effects of magnetic field treatment on chemical composition and water suitability criteria for irrigation (Average of 30 groundwater samples during irrigation events) are presented in Table (3).

Table 3: Effect of magnetic field treatment on irrigation groundwater quality

\begin{tabular}{|c|c|c|c|}
\hline \multicolumn{4}{|c|}{ Water Property } \\
\hline \multirow{2}{*}{\multicolumn{2}{|c|}{ Water Chemical Properties: }} & \multicolumn{2}{|c|}{ Saini } \\
\hline & & $\begin{array}{c}\text { Unmagnetized } \\
\text { Water }\end{array}$ & $\begin{array}{l}\text { Magnetized } \\
\text { Water }\end{array}$ \\
\hline \multicolumn{2}{|c|}{$\mathbf{p H}$} & $7.88 \mathrm{a}$ & $7.97 \mathrm{a}$ \\
\hline \multicolumn{2}{|c|}{ EC $\left(d S ~ m^{-1}\right)$} & $6.81 \mathrm{a}$ & $6.80 \mathrm{a}$ \\
\hline \multirow{3}{*}{$\begin{array}{c}\text { Soluble } \\
\text { Anions } \\
\left(\text { mmolc L L }^{-1}\right) \\
\end{array}$} & $\left(\mathrm{HCO}_{3}{ }^{-}+\mathrm{CO}_{3}{ }^{2-}\right)$ & 5.13 & 5.05 \\
\hline & $\mathbf{C L}^{-}$ & 41.07 & 41.09 \\
\hline & $\mathrm{SO}_{4}{ }^{2-}$ & 10.58 & 10.67 \\
\hline \multirow{4}{*}{$\begin{array}{c}\text { Soluble } \\
\text { Cations } \\
\left(\text { mmolc L }^{-1}\right)\end{array}$} & $\mathrm{Ca}^{2+}$ & 8.22 & 8.20 \\
\hline & $\mathbf{K}^{+}$ & 0.21 & 0.23 \\
\hline & $\mathrm{Mg}^{2+}$ & 7.54 & 7.53 \\
\hline & $\mathrm{Na}^{+}$ & 40.81 & 40.85 \\
\hline \multicolumn{4}{|c|}{$\begin{array}{l}\text { Chemical criteria: } \\
\end{array}$} \\
\hline \multicolumn{2}{|c|}{ Sodium adsorption ratio (SAR) } & $14.52 \mathrm{a}$ & $13.58 \mathrm{a}$ \\
\hline \multicolumn{2}{|c|}{$\mathrm{Ca}^{2+1} \mathrm{Mg}^{2+}$ Ratio } & $1.09 \mathrm{a}$ & $1.06 \mathrm{a}$ \\
\hline \multicolumn{2}{|c|}{ Magnesium Hazard (M.H.) } & $47.84 \mathrm{a}$ & $48.44 \mathrm{a}$ \\
\hline \multicolumn{2}{|c|}{$\mathrm{Na}^{+} / \mathrm{Cl}^{-}$Ratio } & $1.01 \mathrm{a}$ & $0.89 \mathrm{~b}$ \\
\hline \multicolumn{2}{|c|}{ Sodium percentage $(\mathrm{Na} \%)$} & $72.24 \mathrm{a}$ & $72.23 \mathrm{a}$ \\
\hline \multicolumn{2}{|c|}{ permeability index (\%) } & $76.14 a$ & $76.16 \mathrm{a}$ \\
\hline
\end{tabular}

* Figures followed by the same letters through entire rows are insignificantly different at $<5 \%$ probability level

Results of this research indicated that groundwater is suitable for irrigation in terms of some suitability features responsible for water quality for irrigation such as soluble salt content (EC) associated with sodium adsorption ratio (SAR), $\mathrm{Ca}^{2+} / \mathrm{Mg}^{2+}$ Ratio, Magnesium Hazard (MH\%).

Results of this research indicated that groundwater is unsuitable for irrigation before and after magnetic field treatment in terms of almost all suitability features responsible for water quality for irrigation such as soluble salt content (EC) or sodium adsorption ratio (SAR) as individual measures, main soluble anions and cations, $\mathrm{Ca}^{2+} / \mathrm{Mg}^{2+}$ Ratio, Magnesium Hazard (MH\%), $\mathrm{Na}^{+} / \mathrm{Cl}^{-}$ Ratio, Sodium percentage ( $\mathrm{Na} \%)$, permeability index (\%). By contrast, results of this research indicated that groundwater is suitable for irrigation before and after magnetic field treatment in terms of water reaction $(\mathrm{pH})$.

Irrigation water normal $\mathrm{pH}$ ranges from 6.5 to 8.4, therefor using such water source in soil irrigation may not cause a nutritional inequality or soil $\mathrm{pH}$ sequential changes [4] and [16]. The magnetic process can change the $\mathrm{pH}$ of water [16] and [17].
Sodium adsorption ratio (SAR) values of both magnetized and unmagnetized groundwater were 13.58 and 14.52 indicating insignificant change after applying magnetic field treatment (Table 3). Irrigation with water magnetized or unmagnetized SAR value more than 13 lies under degree of restriction on use "None" if the soil EC is more than $2.9 \mathrm{dS} \mathrm{m}^{-1}$, implying that using such water in peach irrigation may not cause a sodium toxicity or soil infiltration problems in the investigated sandy soil as designated by [18].

By contrast, using the electrical conductivity or SAR as individual measures for irrigation water quality determination, these values lie under the degree of restriction on use "Severe", indicating that using such irrigation water may increase salinity problem in the investigated soil. [19], stated that implementation of physical treatment technology of water by a magnetic device, license to recreate a structure of natural and optimized water in its ability to dissolve soil salts and transport nutritious minerals. Magnetic irrigation water treatment allows irrigation with saline water without any detrimental impacts on crops.

Evaluation of the potential soil infiltration rate problem using SAR and ECw together, soil infiltration rate generally increases with increasing water salinity [20], and decreases with either decreasing salinity or increasing sodium content relative to calcium and magnesium. Therefore, these two factors, salinity and SAR, must be considered together for a proper evaluation of the ultimate effect on water infiltration rate. An infiltration problem occurs if irrigation water does not enter soils rapidly enough during a normal irrigation cycle to replenish soil with water needed by crop before next irrigation [18].

Soil infiltration problem, however, affected by many factors other than irrigation water quality, including soil physical and chemical characteristics such as type of clay minerals, soil texture and exchangeable cations.

Also, calcium to magnesium $(\mathrm{Ca} / \mathrm{Mg})$ ratio was a bit more than 1.0 before and after magnetic field treatment of the investigated groundwater, suggesting that using this water in irrigation may cause a calcium deficiency problem or soil infiltration problems [4] and [21]. Ca: $\mathrm{Mg}$ ratio less than one boosts formation of sodic soils and more so quick and effective of sandy soils.

In general, higher magnesium waters and soils are emergent cases of water quality deterioration and soil degradation leading to environmental and food security limitations with different irrigation systems. A ratio of magnesium-to-calcium more than 1 in irrigation waters and an exchangeable magnesium percentage more than $25 \%$ in soils are considered high enough to result in soil degradation and productivity decline [4]. Magnetized groundwater samples under investigation in general have $\mathrm{Na} / \mathrm{Cl}$ ratios that are lower than one (magnetized $=0.89$ ) indicating the positive effect of magnetic field treatment on irrigation water and implying little effect of sodium and chloride on the investigated sandy soil.

Whereas, unmagnetized groundwater samples have $\mathrm{Na} / \mathrm{Cl}$ ratios that are higher than one (unmagnetized $=1.01$ ), implying high effect of sodium and chloride on the investigated sandy soil 
under repeated irrigation with such water. Chloride content is very important for groundwater suitability for irrigation purposes where chloride ions are toxic and most plants are very sensitive for chloride in irrigation water. [22], indicated that chloride ions are very strongly absorbed by plants compared to other ions and some plants have the aptitude to accumulate chlorides even from water with low chloride concentration.

Higher levels of water salinity and lower irrigation intervals significantly increased the initial soil electrical conductivity, soil salinity build up, and soil $\mathrm{pH}$ due to increased water salinity levels and inadequate irrigation and drainage water. In general, no significant changes in the most investigated water quality indices between magnetized water and unmagnetized were observed by magnetic field treatment (Table 3). However, data reflected high concentrations of chloride and sodium contents in the investigated groundwater in comparison to bicarbonate, sulfate, calcium, magnesium and potassium.

Regarding chloride toxicity problem related to irrigation water quality, chloride concentration in both magnetized or unmagnetized groundwater was in range of $41.09-41.07$ $\operatorname{mmol}_{c} L^{-1}$ which lies under the degree of restriction on use "Severe", suggesting that using such water in irrigation may cause a severe chloride toxicity problem. In addition, potential sodium toxicity is very high due to that soluble sodium $(40.85$ to $40.81 \mathrm{mmol}_{\mathrm{c}} \mathrm{L}^{-1}$ ) is higher than summation of soil main cations of calcium, magnesium and potassium (15.96 to 15.97 $\mathrm{mmol}_{\mathrm{c}} \mathrm{L}^{-1}$ ) whether in magnetized or unmagnetized irrigation groundwater. Standard sodium toxicity symptoms are the leaf burn, scorch and dead tissue along outside edges of leaves in contrast to symptoms of chloride toxicity which normally occur initially at extreme leaf tip.

Results of this study displayed that drip emitters were subjected to deposits accumulating near small openings, resulting in some emitters blockage.

Irrigation with magnetized groundwater using drip irrigation method is a good technique nowadays to avoid or exact a deposit problem and to reduce soluble salts in the plant root zone.

The physical treatment technology of water by a magnetic field with suitable strengths and frequency, give rise to restructure adjusted water able to dissolve and transport salts. Magnetic field treatment of irrigation saline water permits irrigation without any harmful impacts on field crops [23] and [24]. Research data agree with that reported by [4].

Assessment of groundwater quality for irrigation is very important for newly reclaimed desert lands that contingent mainly on the groundwater as a principal source. Results of this research indicated that irrigation water salinity and water scarcity are major constraints to sustainable use of desert land for agriculture in the under arid and semiarid regions. Several studies demonstrated that MWT influences molecular and physicochemical properties of water that alter the quality of water [25].
The origin of physical and chemical modulations of water molecules under magnetic treatment is the alteration of water nucleus [25].

The effects of magnetic treatment on irrigation water include increasing the number of crystallization centers this is effect improve the quality of irrigation water. The important components for effective magnetic treatment are flow rate through the apparatus and certain chemical parameters of water, namely, carbonate water hardness of more than $50 \mathrm{mg} / \mathrm{L}$ and concentration of hydrogenous ions in water at $\mathrm{pH}>7.2$ [26]. Magnetic treatment of water has been reported to change some of the physical and chemical properties of water, mainly hydrogen bonding, polarity, surface tension, conductivity, $\mathrm{pH}$ and solubility of salts [27].

It was observed that magnetized water helps in dissolving minerals and acids by a higher rate than unmagnetized water and increasing the speed of chemical reactions [27].

Sustainable agriculture in Sinai Peninsula is administered by availability and quality of groundwater resources. Irrespective of the ability of magnetic field treatment to slightly change chemical composition and criteria of magnetized water than in unmagnetized groundwater, however, the suitability classes of magnetized water still situated at the same categories of unmagnetized water. However, under the conditions of this study when magnetized water was used in irrigation, soil properties and maize crop production were changed significantly compared to irrigation with unmagnetized water. Magnetic water treatment does not change chemical parameters of water. however, it changes physical parameters and according to some authors, magnetic fields have effect on reduction of surface tension, viscosity, zeta potential, solubility, and diffusion [28].

Magnesium hazard index increased from $47.84 \%$ to $48.44 \%$ after using magnetic water treatment, but the magnesium ratio not more than $50 \%$ can be used for safe irrigation. Magnesium ratio of more than $50 \%$ in irrigation water considers poisonous to plants and detrimental on soil properties. In addition, high levels of $\mathrm{Mg}^{2+}$ in irrigation water increase magnesium hazard index due to increased exchangeable $\mathrm{Na}^{+}$in irrigated soils and this might cause damage for soil structure and affects crop yields and soil quality by increased alkalinity in the current study area.

Irrigation water with chloride $\left(\mathrm{Cl}^{-}\right)$concentrations exceed 10 $\mathrm{mg} \mathrm{L}^{-1}$ lies under degree of restriction on use " Severe " implying that using such water in maize irrigation may cause a chloride toxicity problem as described by [18]. After water magnetic treatment, chloride concentration in magnetized irrigation water increased from 41.07 to $41.09 \mathrm{mg} \mathrm{L}^{-1}$.

Also, after water magnetic treatment, sodium concentration in magnetized irrigation water increased from 40.81 to $41.85 \mathrm{mg} \mathrm{L}^{-1}$.

Sodium $\left(\mathrm{Na}^{+}\right)$concentrations exceeded $9 \mathrm{mg} \mathrm{L}^{-1}$ in irrigation water lies under degree of restriction on use" Severe " implying that using such water in maize irrigation may cause a sodium toxicity problem as described by [18]. 
As it is recognized that sodium and chloride are some of the most undesirable ions in soil, using such water in irrigation may cause a severe sodium and chloride toxicity problems as they have very strong negative impact soil and plant growth and yield.

As indicated by this experiment results, magnetic field treatment of irrigation water caused leaching salts below root zones, reduced sodium and chloride accumulation, decreased $\mathrm{Na} / \mathrm{Cl}$ ratio from 1.01 to 0.89 in magnetized water resulting in alleviation of sodium and chloride negative impacts on maize plants in the root zone.

The percentage of sodium $(\mathrm{Na} \%)$ is also commonly utilized for assessing the suitability of water quality for irrigation [29]. In groundwater, the increase of sodium concentration generates undesirable effects as the sodium reacts with the soil in order to decrease the permeability of soil and growth of plants [30]. Standard sodium toxicity symptoms are the leaf burn, scorch and dead tissue along outside edges of leaves in contrast to symptoms of chloride toxicity which normally occur initially at extreme leaf tip.

The results in Table 3 indicated that the level of $(\mathrm{Na} \%)$ decreased after using magnetized water from $72.24 \%$ to 72.23 $\%$, which is within the severe limits. Magnetic treatment may be assisting to reduce the $\mathrm{Na}$ toxicity at cell level by detoxification of $\mathrm{Na}^{+}$, either by restricting the entry of $\mathrm{Na}^{+}$at membrane level or by reduced absorption of $\mathrm{Na}^{+}$by plant roots [31].

Also, the increase of soil permeability increases the presence of sodium, calcium, magnesium and bicarbonate in the soil [32].

The Permeability Index (PI\%) is used to indicate the suitability of water for irrigation. The permeability index insignificantly increased after using magnetic field treatment of groundwater from $76.14 \%$ to $76.16 \%$. These values of PI of irrigation groundwater can be classified into Class III (>75\%) as unsuitable for irrigation according to [14].

Generally, when water is subjected to magnetic field, the water molecules will arrange in one direction. this mode of arrangement is caused by relaxation bonds, then the bond angle decreases to less than $105^{\circ}$ leading to decrease in the consolidation degree between water molecules, and increase in size of molecules. for these reasons, the viscosity of magnetic water is less. Then viscosity of normal water. this change in water molecules composite causes a change in permeability pressure, surface tension, $\mathrm{pH}$ and electric conduction [19].

Results of this research confirmed that implementation of magnetic treatment technology of saline irrigation water by a magnetic device optimized water in its ability to dissolve soil salts and ensures to lessen salts in the root zone and an increase transport of nutritious minerals. In general, magnetic irrigation water treatment allows irrigation with magnetized saline water with little detrimental impacts on maize crops compared to irrigation with unmagnetized water.

\subsection{Impacts of magnetic field treatment on water and NPK}

\section{fertilizer use efficiencies and maize crop productivity.}

Water use efficiency and productivity were assessed mainly by moisture content in root zone, discharge emitter $\left(\mathrm{L} \mathrm{h}^{-1}\right)$, clogging emitter $\%$ and accordingly drip irrigation system application efficiency. Whereas, crop productivity was assessed mainly by both water use efficiency (WUE, $\mathrm{kg} \mathrm{kg}^{-1}$ ) and fertilizer use efficiency (FUE, $\mathrm{kg} \mathrm{kg}^{-1}$ ) as indicators used to calculate the increase of the crop yield per unit of water or fertilizer.

It was hypnotized that irrigation with magnetized water will increase water and fertilizer use efficiencies and consequently crop yield compared to irrigation with unmagnetized groundwater. Results on the effect of magnetic field treatment on these properties after irrigation with magnetized and unmagnetized groundwater are presented in Table (4).

Table 4. Impacts of magnetic field treatment on soil moisture properties and water and fertilizers use efficiency.

\begin{tabular}{|l|l|l|l|l|}
\hline Treatment & $\mathbf{T}_{\mathbf{0}(\text { control) }}$ & $\mathbf{T}_{\mathbf{1}(\mathbf{1 0 0})}$ & $\mathbf{T}_{\mathbf{2 ( 2 0 0 )}}$ & $\mathbf{T}_{\mathbf{3 ( 3 0 0 )}}$ \\
\hline Moisture content in root zone & $8.37 * \mathrm{c}$ & $11.47 \mathrm{a}$ & $10.88 \mathrm{a}$ & $9.45 \mathrm{~b}$ \\
\hline Application efficiency \% & 64.07 & 72.62 & 69.91 & 68.11 \\
\hline Water use efficiency WUE $\left(\mathbf{k g ~ k g}^{-1}\right)$ & $1.02 \mathrm{~cd}$ & $1.97 \mathrm{a}$ & $1.57 \mathrm{~b}$ & $1.06 \mathrm{~d}$ \\
\hline Nitrogen use efficiency NUE $\left(\mathbf{k g ~ k g}^{-1}\right)$ & $1.16 \mathrm{c}$ & $4.11 \mathrm{a}$ & $2.85 \mathrm{~b}$ & $2.40 \mathrm{~d}$ \\
\hline Phosphor use efficiency PUE $\left(\mathbf{k g ~ k g}^{-1}\right)$ & $1.21 \mathrm{c}$ & $4.31 \mathrm{a}$ & $2.99 \mathrm{~b}$ & $2.51 \mathrm{~d}$ \\
\hline Potassium use efficiency KUE $\left(\mathbf{k g ~ k g}^{-1}\right)$ & $1.16 \mathrm{c}$ & $4.13 \mathrm{a}$ & $2.86 \mathrm{~b}$ & $2.41 \mathrm{~d}$ \\
\hline
\end{tabular}

* Figures followed by the same letters through entire rows are insignificantly different at $<5 \%$ probability level

Impacts of magnetic field treatment on water use efficiency (WUE) were evaluated in terms of moisture uniformity distribution and content in root zone, application efficiency, while fertilizer use efficiency (FUE) was assessed by calculating nitrogen use efficiency (NUE), phosphorus use efficiency (PUE) and potassium use efficiency (KUE).

In general, irrigation with magnetized water increased significantly soil moisture content in the soil root zone from $8.37 \%$ for control treatment (irrigated with unmagnetized water) to $11.47 \%$ in the first $100 \mathrm{~m}$ irrigation distance from the magnetic field device.

Moisture content in root zone decreased insignificantly as the irrigation distances increased from 100 to $200 \mathrm{~m}$ and $300 \mathrm{~m}$ distances from the magnetic field device (Table 4).

This indicates that effect of magnetic treatment on irrigation water decreases as the irrigation distance increases from the magnetic device at the head of the field. Water use efficiency and NPK use efficiencies. As water and fertilizer use efficiency is based on the amount of fertilizer and water units required to produce the yield units, thus, the efficiency of water productivity and $\mathrm{N}$ use efficiency for maize (Table 4) increased from 1.02 for water use efficiency and 1.16 for nitrogen use 
efficiency before magnetic treatment to 1.97 and $4.11 \mathrm{Kg} \mathrm{Kg}^{-1}$, respectively.

Irrigation with magnetized water increases water and fertilizer uptake and enhances plant growth and metabolism and crop productivity compared to irrigation with unmagnetized water [32].

Variations in soil water distribution uniformity in the investigated drip irrigation increased with irrigation by magnetized water compared to unmagnetized water resulting in increased application efficiency of the drip irrigation system from $64.07 \%$ for control to $72.62 \%$ for irrigation with magnetized water at the irrigation distance of $100 \mathrm{~m}$. Therefore, the use of magnetized water for drip irrigation is recommended to achieve higher irrigation system application efficiency and consequently crop yields and productivity.

Dripper discharge and distribution uniformity were higher for drip irrigation with magnetic water compared to non-magnetic water [34].

The magnetic water showed a significant effect $(P \leq 0.01)$ on distribution uniformity of drippers.

Limited or comprehensive dripper clogging causes lower water application uniformity and therefore declines crop production and irrigation efficiency [34].

All the confined soil moisture contents for the magnetized and control treatments were evaluated using (Golden Software, Inc., Golden, $\mathrm{CO}$ ) program as moisture contents in soils are the key element to evaluate efficiency of a drip irrigation system where the moisture content depends on emitters discharge amount and clogging rates. Results of this study showed that wetted soil volume more than or equal $100 \%$ from field capacity in root zone $\left(\mathrm{WSV}_{\geq 100 \% \mathrm{FC}}\right.$ ) (moisture content in root zone) increased significantly in plots irrigated with magnetized water compared to control treatment. $\left(\mathrm{WSV}_{\geq 100 \% \mathrm{FC}}\right)$ in root zone decreased insignificantly as the irrigation distances increased from the magnetic device.

Effects of magnetic water on wetted soil volume more than or equal $100 \%$ from field capacity in root zone $\left(\mathrm{WSV}_{\geq 100 \% \mathrm{FC}}\right)$ in root zone was determined by calculating the wetted soil volume surrounded by contour line 10.6 which approximately representing the field capacity. The wetted soil volume surrounded by contour line 10.6 turned to uniform volume. Figures (1, 2, 3 and 4) showed the relation between magnetized water and unmagnetized water and average the taller design drip irrigation on wetted soil volume $" \mathrm{WSV}_{\geq 100 \% \mathrm{FC}}$ " in root zone and also illustrate the effect of magnetized water on moisture content in root zone "MCRZ" under magnetized water.

$\mathrm{WSV}_{\geq} 100 \% \mathrm{FC}$ at magnetized water under (control unmagnetized) was too small at control. the average of maximum width for contour line 10.55 from the emitter to 25 $\mathrm{cm}$ length was $2.22 \mathrm{~cm}$ and maximum depth was $30.71 \mathrm{~cm}$, this mean the area of $\mathrm{WSV}_{\geq 100 \% \mathrm{FC}}$ was $68.18 \mathrm{~cm}^{2}$ and average of maximum width for contour line 10.55 from the emitter across lateral was $31.66 \mathrm{~cm}$ hence, $\mathrm{WSV}_{\geq 100 \% \mathrm{FC}}$ was $2575.68 \mathrm{~cm}^{3}$

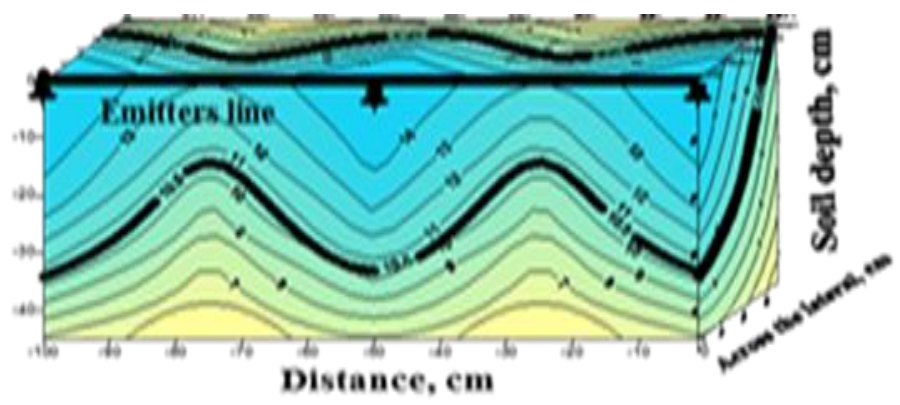

Figure (1). Three dimensional soil moisture distribution and wetted soil volume with (unmagnetized water control)

$\mathrm{WSV}_{\geq 100 \% \mathrm{FC}}$ at magnetized water under $(100 \mathrm{~m})$ was the average of maximum width for contour line 10.55 from the emitter to $25 \mathrm{~cm}$ length was $2.51 \mathrm{~cm}$ and maximum depth was $32.38 \mathrm{~cm}$, this mean the area of $\mathrm{WSV}_{\geq 100 \% \mathrm{FC}}$ was $81.27 \mathrm{~cm}^{2}$ and average of maximum width for contour line 10.55 from the emitter across lateral was $35.92 \mathrm{~cm}$ hence, $\mathrm{WSV}_{\geq 100 \% \mathrm{FC}}$ was $2919.24 \mathrm{~cm}^{3}$.

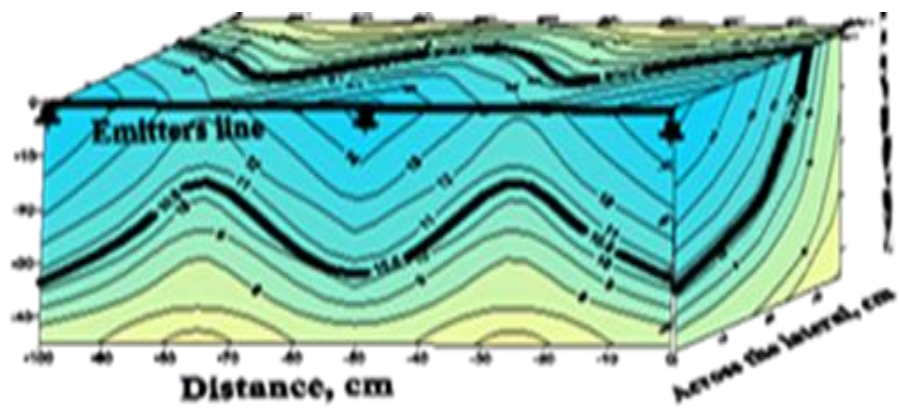

Figure (2). Three dimensional soil moisture distribution and wetted soil volume with (magnetized water and $100 \mathrm{~m}$ ).

$\mathrm{WSV}_{\geq 100 \% \mathrm{FC}}$ at magnetized water under $(200 \mathrm{~m})$ was the average of maximum width for contour line 10.55 from the emitter to $25 \mathrm{~cm}$ length was $2.48 \mathrm{~cm}$ and maximum depth was $32.43 \mathrm{~cm}$, this mean the area of $\mathrm{WSV}_{\geq 100 \% \mathrm{FC}}$ was $80.43 \mathrm{~cm}^{2}$ and average of maximum width for contour line 10.55 from the emitter across lateral was $34.94 \mathrm{~cm}$ hence, $\mathrm{WSV}_{\geq 100 \% \mathrm{FC}}$ was $2810.33 \mathrm{~cm}^{3}$.

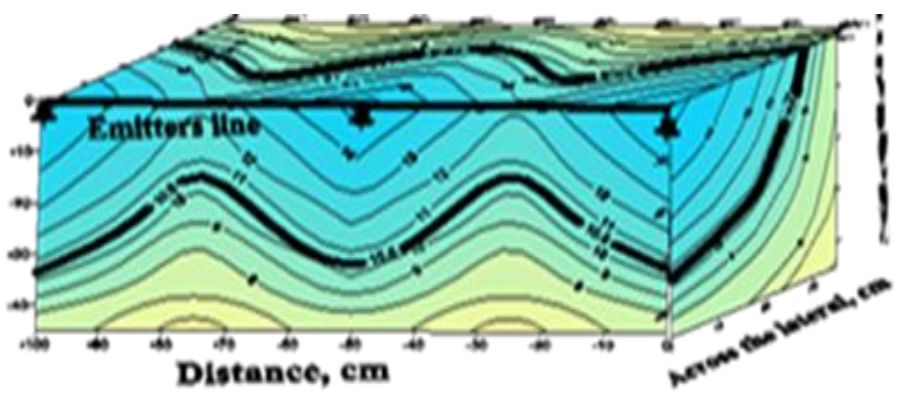

Figure (3). Three dimensional soil moisture distribution and wetted soil volume with (magnetized water and $200 \mathrm{~m}$ ) 
$\mathrm{WSV}_{\geq 100 \% \mathrm{FC}}$ at magnetized water under $(300 \mathrm{~m})$ was the average of maximum width for contour line 10.55 from the emitter to $25 \mathrm{~cm}$ length was $2.11 \mathrm{~cm}$ and maximum depth was $33.78 \mathrm{~cm}$, this mean the area of $\mathrm{WSV}_{\geq 100 \% \mathrm{FC}}$ was $71.28 \mathrm{~cm}^{2}$ and average of maximum width for contour line 10.55 from the emitter across lateral was $38.41 \mathrm{~cm}$ hence, $\mathrm{WSV}_{\geq 100 \% \mathrm{FC}}$ was $2738.06 \mathrm{~cm}^{3}$

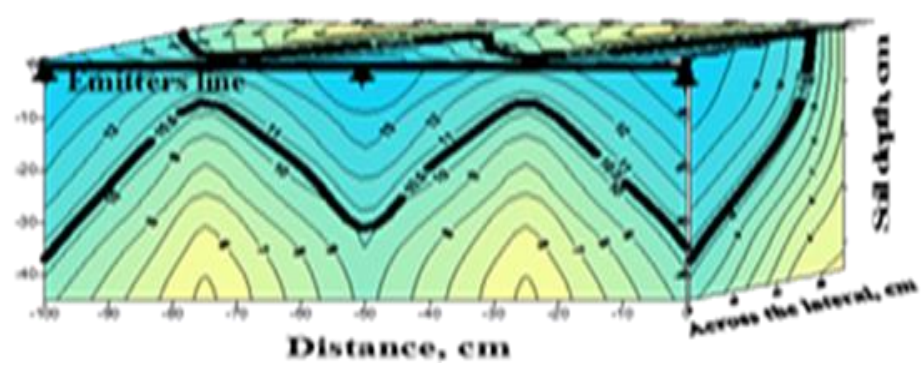

Figure (4). Three dimensional soil moisture distribution and wetted soil volume with (magnetized water and $300 \mathrm{~m}$ )

Results showed that, irrigation with unmagnetized water (control), wetted front area and wetted soil volume were $68.18 \mathrm{~cm}^{2}$ and $2575.68 \mathrm{~cm}^{3}$ reflecting low water application efficiency of $64.07 \%$, while wetted front area and wetted soil volume were $81.27 \mathrm{~cm}^{2}$ and $2919.24 \mathrm{~cm}^{3}$ reflecting high water application efficiency of $72.62 \%$, for irrigation with magnetized water at drip irrigation distance of $100 \mathrm{~m}$ from the magnetic device.

Also, wetted front area and wetted soil volume were $80.43 \mathrm{~cm}^{2}$ and $2810.33 \mathrm{~cm}^{3}$ reflecting high water application efficiency of $69.91 \%$, for irrigation with magnetized water at drip irrigation distance of $200 \mathrm{~m}$, respectively.

Soil wetted front area and wetted soil volume were $71.28 \mathrm{~cm}^{2}$ and $2738.06 \mathrm{~cm}^{3}$ reflecting low water application efficiency of $68.11 \%$, for irrigation with magnetized water at drip irrigation distance of $300 \mathrm{~m}$, respectively.

Differences detected and influenced by the magnetic field treatment rely on numerous parameters, including magnetic field strength, path of magnetic field, time of magnetic contact, solution discharge, irrigation distances and water viscosity and $\mathrm{pH}$ [34].

Irrigation with magnetized water showed high significant influence on soil wetted front area and wetted soil volume reflecting high distribution uniformity and water application efficiency compared to control (irrigation with unmagnetized water).

The reason that soil moisture was higher for the magnetized irrigation water might be due to that water molecules are released to make the water more cohesive as influenced by hydrogen bonds and Van der Waals forces. Thus, the water molecules were easily attached to soil particles and did not leach to lower depths and also the water molecules easily penetrated into the micro spaces of soil particles and were thus impeded from moving to the lower depths [24] and [35].
In general, magnetic water treatment showed significant impact on dripper discharge $\left(\mathrm{L} \mathrm{h}^{-1}\right)$, uniformity of distribution of water, emission uniformity, and moisture content in root zone $\%$ and the dripper discharge variations. In conclusions, magnetic field treatment of irrigation water can improve fertigation performance in drip irrigation systems. Fertigation of NPK fertilizers using magnetized water compared to unmagnetized water increased the dripper discharge which indicates less dripper clogging and higher distribution uniformity causing increased water and fertilizer use efficiencies and consequently increased maize crop yield per unit of water or fertilizer and quality parameters [24] and [35].

The results showed that the dripper discharge average, distribution uniformity of soil moisture, moisture content in root zone $\%$ and accordingly maize crop yield per unit of water or NPK fertilizers required are significantly influenced by type of irrigation water (magnetized and unmagnetized) and drip irrigation distances $(100,200$ and 300m) from the magnetic treatment device.

This data point to increased available water in a such coarse textured sandy soil and high solubility of nitrogen, phosphate and potassium under the influence of the magnetic treatment, showing clear influence of the magnetic treatment on the increase in water availability and nutritional solubility and accordingly maize crop yield.

The main functions of magnetic treated water in soil are increasing the leaching of excess soluble salts, lowering $\mathrm{pH}$ values of soil layers, dissolving slightly soluble salts such as carbonates, phosphates and sulfates [36], decreasing the hydration of salt ions, accelerating coagulation and salt crystallization, increasing the efficiency of added fertilizers, increasing nutrient mobility in soil and enhancing extraction and uptake of N, P, K, Fe and Zn by plants [37].

Under arid conditions, efficient water and fertilizer use permit the use of more arable land to produce more agricultural crops. Therefore, the adoption of modern methods and means of irrigation with high efficiencies such as magnetic water treatment is very important and necessary to increase the production and provide adequate food. In sandy soil agricultural management, fertilization with irrigation (fertigation) is an important means to rationalize the fertilizer proper usage because they are characterized by a high infiltration and water losses and a low fertility and organic matter.

\subsection{Impacts of irrigation with magnetized water on the}

\section{investigated sandy soil properties.}

Investigated sandy soil properties assessed mainly by $\mathrm{pH}$, soluble salt content $\left(\mathrm{EC}_{\mathrm{e}}\right)$, main soluble cations and anions, and sodium adsorption ratio (SAR).

Results on the effects of magnetized water on these soil properties are presented in Table (5). 
Table 5: Impacts of magnetized water on the investigated sandy soil properties.

\begin{tabular}{|c|c|c|c|c|c|c|c|}
\hline \multirow{2}{*}{\multicolumn{2}{|c|}{\begin{tabular}{|l} 
Irrigation distance $(\mathrm{m})$ \\
\end{tabular}}} & \multicolumn{3}{|c|}{$\begin{array}{l}\text { Soil irrigated with } \\
\text { Magnetized Water }\end{array}$} & \multicolumn{3}{|c|}{$\begin{array}{l}\text { Soil irrigated with } \\
\text { Unmagnetized Water }\end{array}$} \\
\hline & & $0-100$ & $100-200$ & $200-300$ & 0 - 100 & $1000-200$ & $200-300$ \\
\hline \multicolumn{2}{|c|}{ Field Capacity \% } & $12.95 \mathrm{a}$ & $11.89 \mathrm{a}$ & $10.88 \mathrm{~b}$ & $10.65 b$ & $10.58 \mathrm{~b}$ & $10.49 \mathrm{~b}$ \\
\hline \multicolumn{2}{|l|}{ Wilting Point \% } & $3.46 \mathrm{a}$ & $3.39 \mathrm{a}$ & $3.41 \mathrm{a}$ & $3.56 \mathrm{a}$ & $3.68 \mathrm{a}$ & $3.59 \mathrm{a}$ \\
\hline \multicolumn{2}{|l|}{ Available Water } & $9.49 \mathrm{a}$ & $8.5 \mathrm{~b}$ & $7.47 \mathrm{c}$ & $7.09 \mathrm{c}$ & $6.90 \mathrm{c}$ & $6.90 \mathrm{c}$ \\
\hline \multicolumn{2}{|c|}{ Bulk Density $\mathbf{g} / \mathrm{cm}^{3}$} & 1.42 & 1.48 & 1.46 & 1.61 & 1.58 & 1.59 \\
\hline \multicolumn{8}{|c|}{ Soil Chemical Properties: } \\
\hline \multicolumn{2}{|c|}{ pH $(1: 2.5)$} & 8.13 & 8.11 & 8.20 & 8.33 & 8.31 & 8.36 \\
\hline \multicolumn{2}{|c|}{$E C(1: 5)\left(\mathrm{dS} \mathrm{m}^{-1}\right)$} & 3.01 & 3.12 & 3.14 & 3.22 & 3.31 & 3.17 \\
\hline \multicolumn{2}{|c|}{$\mathrm{CaCO}_{3} \mathrm{~g} \mathrm{~kg}^{-1}$} & $20.44 a$ & $19.55 \mathrm{a}$ & $17.97 \mathrm{a}$ & $29.13 \mathrm{e}$ & $27.15 \mathrm{e}$ & $22.29 \mathrm{c}$ \\
\hline \multirow{3}{*}{$\begin{array}{l}\text { Soluble Anions } \\
\left(\text { mmolc L }^{-1}\right)\end{array}$} & $\left(\mathrm{HCO}_{3}^{-}+\mathrm{CO}_{3}{ }^{2-}\right)$ & 5.27 & 5.55 & 6.88 & 7.70 & 7.78 & 7.54 \\
\hline & $\mathbf{C L}^{-}$ & $3.26 \mathrm{a}$ & $6.83 b$ & $12.22 \mathrm{c}$ & $11.23 \mathrm{c}$ & $11.09 \mathrm{c}$ & $11.43 \mathrm{c}$ \\
\hline & $\mathrm{SO}_{4}{ }^{2-}$ & 3.01 & 6.32 & 10.00 & 12.64 & 12.63 & 12.82 \\
\hline \multirow{4}{*}{ 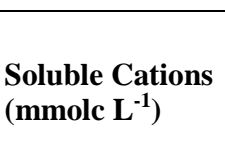 } & $\mathrm{Ca}^{2+}$ & 2.55 & 4.43 & 7.02 & 9.22 & 9.35 & 9.57 \\
\hline & $\mathbf{K}^{+}$ & 0.05 & 0.07 & 0.09 & 0.21 & 0.14 & 0.16 \\
\hline & $\mathrm{Mg}^{2+}$ & 1.02 & 2.32 & 2.94 & 3.33 & 3.41 & 3.55 \\
\hline & $\mathrm{Na}^{+}$ & $7.92 a$ & $11.88 \mathrm{~b}$ & $19.05 \mathrm{c}$ & $18.81 \mathrm{c}$ & $18.60 \mathrm{c}$ & $18.51 \mathrm{c}$ \\
\hline \multicolumn{2}{|c|}{ Sodium adsorption ratio (SAR) } & $5.91 \mathrm{a}$ & $6.46 b$ & $8.54 \mathrm{c}$ & $7.52 \mathrm{c}$ & $7.35 \mathrm{c}$ & $7.23 c$ \\
\hline
\end{tabular}

* Figures followed by the same letters through entire rows are insignificantly different at $<5 \%$ probability level

Results showed that, at all soil depths below the emitters, the levels of mean soil soluble cation and anions measured in the soil irrigated with magnetized saline water were less than the soil irrigated with unmagnetized saline water and the differences were significant at a 5\%level. Also, it was observed a significant decrease in soil salinity (EC, and SAR) in soils irrigated with magnetically treated saline water compared to the soils irrigated with unmagnetized saline water.

This probably occurred because of the changes in the arrangement of particles and polarization of the solution that took place when the liquids passed through the magnetic field [38]. This magnetized water seemed to increase the leachability of salts downwards the soil profile.

This might indicate the higher efficiency of the magnetized water in leaching soluble salts out of the soil profile than the unmagnetized water. The magnetic field might change hydrogen bonds between water molecules and rebuilt them in hexagonal structure consequently increased the leachability of the soluble salts. Several researchers confirmed that the magnetized water increased solubility and leachability of salts from the soil profile [38].

The clay soils recorded less efficiency in the leachability of soluble salts throughout the soil columns than the sandy soils. Furthermore, compared to control, magnetic treatment had a significant effect on bicarbonate, chloride, sulfate, calcium, potassium, magnesium and sodium, contents in the soil. It is known that sodium and chloride are some of the most undesirable ions in soil as they have very strong negative impacts on plant growth and yield.

The results shown in table 5 showed that irrigation with the magnetically treated water has an effective effect on reducing sodium and chloride in the root zone of the investigated sandy soil.
Magnetic treatment of irrigation water has demonstrated the ability to reduce water consumption and improve crop yield and plant growth. In general, the three main observed effects of magnetic treatment in soils are the removal of excess soluble salts, lowering of $\mathrm{pH}$ values, and the dissolving of slightly soluble components such as phosphates, carbonates and sulfates [39].

Results by [39], indicated that the rate of salt accumulation was greater in the control group at the $30-60 \mathrm{~cm}$ depth. At the same time, the salt content at the $90 \mathrm{~cm}$ depth was greater in the magnetic treatment water MTW column.

The results have shown that MTW changes the distribution of salts between soil layers reducing their content in the upper layers which are more important for agriculture.

Magnetic water treatment technologies are needed to reduce the rate of salt accumulation and improve the leaching of salts below the root zones of salt-sensitive agricultural crops and in general in salt-affected soils under arid conditions [24] and [35]. An additional interesting finding of this study, was that the total distribution area and volume of water, soil field capacity and consequently the available water in the investigated sandy soil irrigated with magnetized water was higher than soils irrigated with unmagnetized water.

It could be assumed that saline irrigation water after magnetic treatment has higher capacity to stay in such sandy soil due to reduction of magnetized water surface tension and viscosity [24], [35] and [40].

Results by [40], indicated that magnetic field treatment of water decreased the contact angle of water and increased water ability to enter into soil micropores.

Thus, the investigated sandy soil irrigated with magnetized water had a higher water holding capacity and soil field capacity compared to the control soil irrigated with unmagnetized water. 
Sustainable development in the Sinai Desert of Sinai Governorate is controlled by availability and quality of agricultural land and groundwater resources.

\section{4- Conclusions}

It could be concluded that, magnetic treatment of saline water used in irrigating desert sandy soils could be a promising friendly and environmental technology for soil and agricultural improvements under arid conditions. Based on this research results, it is recommended to use the magnetized water for irrigation to increase the fertilizers use efficiency, to improve maize crop productivity and to save the irrigation water especially under water shortage conditions. Irrigation with magnetized irrigation water caused higher soil moisture compared with the control at different irrigation events. In addition, significant improvements in the soil chemical properties (i.e. $\mathrm{pH}, \mathrm{ECe}, \mathrm{Na}+, \mathrm{Cl}-$, and soil SAR) occurred due to irrigation with magnetized saline water compared to irrigation with unmagnetized saline groundwater (control treatments).

Results of this research confirmed that using such groundwater in irrigation may cause a severe salinity build up problems in the investigated sandy soil on the long-term if not managed properly.

Even though the results from this study are promising, larger magnetic field treatment strengths and numerous field studies should be conducted to study effects of magnetic treatment technology when irrigation resources are switched from lower salinity Nile water to higher salinity groundwater sources in the Egyptian desert.

\section{5- References}

1-Abd El-Azeim, M. M., M. A. Sherif, M.S. Hussien, I. A. A. Tantawy and S.O. Bashandy (2020). Impacts of nano- and non-nanofertilizers on potato quality and productivity. Ecological Society of China. Published by Elsevier B.V. All rights reserved. Pp: 388-397 https://doi.org/10.1016/j.chnaes.2019.12.007

2- Abdelhafez, A. A., Sh. M. Metwalley and H. H. Abbas, (2020). Water Resources, Types and Common Problems in Egypt. Book chapter in E.-S. E. Omran and A. M. Negm (eds.), Technological and Modern Irrigation Environment in Egypt, Springer Water. https://doi.org/10.1007/978-3-03030375-4_2

3- Omran, E.-S. E. and A. M. Negm, (2020). Technological and Modern Irrigation Environment in Egypt: Best Management Practices and Evaluation book chapter in E.-S. E. Omran and A. M. Negm (eds.), Technological and Modern Irrigation Environment in Egypt, Springer Water, https://doi.org/10.1007/978-3-030-30375-4_1

4- Ben Hassen, H., M. Hozayn, A. Elaoud and A. A. Abdd El-monem, (2020). Inference of Magnetized Water Impact on Salt-Stressed Wheat. Arabian Journal for Science and Engineering (2020) 45:4517-4529 https://doi.org/10.1007/s13369-020-04506-6

5- Dadamouny, M. A., and M. Schnittler, (2016). Trends of climate with rapid change in Sinai, Egypt. Journal of water and clima

6- Al-Gamal, S. A. and M. Sadek, (2015). An assessment of water resources in Sinai Peninsula, using conventional and isotopic techniques, Egypt, Int. J. Hydrology Science and Technology, Vol. 5, No. 3, 241 Copyright (C) Inderscience Enterprises Ltd. https://doi.org/10.1504/IJHST.2015.071351

7- Avery, B. W. and C. L. Bascomb, (1982). Soil survey laboratory methods. Technical Monograph No. 6. Soil Survey, Harpenden, UK.

8- APHA, (2012). Standard methods for the examination of water and wastewater, 22nd edition edited by E. W. Rice, R. B. Baird, A. D. Eaton and L. S. Classer. American Public Health Association (APHA), American Water
Works Association (AWWA) and Water Environment Federation (WEF), Washington, D.C., USA.

9- Liven, P. C. and F. C. Van Rooyen, (1979). The effect of discharge rate and intermittent water application by point - source irrigation on the soil moisture distribution pattern. Soil Sci. amer. J., 43, 8-5.

10- El-Meseery, A. A. (2003). Effect of different drip irrigation systems on maize yield in sandy soil. The 11th Annual Conference of Misr Society of Agr. Eng., 15-16 Oct., 2003: 576 - 594.

11- Barber, S. A. (1976). Efficient fertilizer use. 114-117 p. In F.L. Patteron (ed.) Agronomic research for food. Special Publication 26. American Society of Agronomy, Madison, Wiscosin, USA. https://doi.org/10.2134/asaspecpub26.

12- Richards, L. A. (1954). Diagnosis and Improvement of Saline Alkali Soils, Agriculture, 160, Handbook 60. US Department of Agriculture, Washington DC.

13- Szabolcs, I. and C. Darab, (1964). The Influence of Irrigation Water of High Sodium Carbonate Content of Soils. Proceedings of 8th International Congress of ISSS, Trans II, 803-812.

14- Doneen, L. D. (1964). Water quality for agriculture. University of Calfornia, Department of Irrigation, Davis, p 48

15- Negm, A.M. and A. M Armanuos, (2017). GIS-Based Spatial Distribution of Groundwater Quality in the Western Nile Delta, Egypt. A.M. Negm (eds.), The Nile Delta, Hdb Env Chem 55: 89-120, https://doi.org/10.1007/698_2016_66, Springer International Publishing Switzerland, Published online: 8 November.

16- Karkush, M. O., M. D. Ahmed and S. M. A. Al-Ani (2019). Magnetic Field Influence on The Properties of Water Treated by Reverse Osmosis Engineering, Technology \& Applied Science Research Vol. 9, No. 4, 2019, 4433-4439

17- Baker, J. S. and S. J. Judd (1995). Magnetic amelioration of scale formation, Water Research, Vol. 30, No. 2, pp. 247-260.

18- Avery, B. W. and C. L. Bascomb, (1982). Soil survey laboratory methods. Technical Monograph No. 6. Soil Survey, Harpenden, UK

19- Hachicha, M., B. Kahlaoui, N. Khamassi, E. Misle, and O. Jouzdan, (2018). Effect of electromagnetic treatment of saline water on soil and crops. Journal of the Saudi Society of Agricultural Sciences 17, 154-162 http://dx.doi.org/10.1016/j.jssas.2016.03.003

20- Rhoades, B.E. (1977). A Comparison of Various Definitions of Contractive Mappings. Transactions of the American Mathematical Society, 266, 257-290. https://doi.org/10.1090/S0002-9947-1977-0433430-4

21- Rengasamy, P. and A. Marchuk, (2011). Cation ratio of soil structura stability (CROSS). Soil Res.49, 280-285.

22- Atta, S. A., A. M. Sharaky, A. S. EL Hassanein, and K. M. A. Khallaf, (2007). Salinization of the Groundwater in the Coastal Shallow Aquifer, Northwestern Nile Delta, Egypt. ISESCO Science and Technology Vision, Vol. 3 , Number 4 (November), pp. $112-123$.

23- El-Gindy A. M., Y. E. Arafa, M. Abd El-Hady, H. A. Mansour, and A. E. Mansor, (2018). Effect of Drip Irrigation System Salinity and Magnetic Water Treatment on Turnip Yield and Yield Characters. WWJMRD 4(1): 89-96. 24- Ismail, W. H., E. M. Mutwali, E. A. Salih, and E. T. Tay Elmoula, (2020) Effect of Magnetized Water on Seed Germination, Growth and yield of Rocket Plant (Eruca sativa Mill). SSRG International Journal of Agriculture \& Environmental Science (SSRG-IJAES) - Volume 7 Issue 2 - Mar - April.

25- Cai, R., et al., (2009). The effects of magnetic fields on water molecular hydrogen bonds. Journal of Molecular Structure, 938(1): p. 15-19.

26- Bogatin, J., et al., (1999). Magnetic treatment of irrigation water: experimental results and application conditions. Environmental science \& technology, 33(8): p. 1280-1285.

27- Ulaiwi, W. S. (2012). The Effect of Magnetic Field on the Solubility of $\mathrm{Na} 2 \mathrm{CO} 3$ and $\mathrm{Na} 2 \mathrm{CO} 3 . \mathrm{H} 2 \mathrm{O}$ at Different Temperature and $\mathrm{pH}$ Values. Egypt. J. Chem. 55, No.3, pp. 213-221

28- Chang, K. T. and C. I. Weng, (2006). An investigation into the structure of aqueous $\mathrm{NaCl}$ electrolyte solutions under magnetic fields. Computational Materials Science. 43(4):1048-55.

29- Wilcox, L. V. (1948). Classification and use of irrigation waters. U.S. Department of Agriculture, Washington DC, p 962.

30- Vasanthavigar, M., K. Srinivasamoorthy, K, Vijayaragavan, R. R. Ganthi, S. Chidambaram, P. Anandhan, M. S. Singh, R. Vannan and S. Vasudevan. (2010). Application of water quality index for groundwater quality assessment: Thirumanimuttar sub-basin, Tamilnadu, India. Environ Monit Assess 171(1):595-609.

31- Maheshwari, B. L. and H. S. Grewal, (2009). Magnetic treatment of irrigation water: Its effects on vegetable crop yield and water productivity. Agricultural water management, 96(8): p. 1229-1236 https://doi.org/10.1016/j.agwat.2009.03.016

32- Chandu, S. N., N. V. Subbarao, and S. R. Prakash, (1995). Suitability of groundwater for domestic and irrigational purposes in some parts of Jhansi District, U.P.Bhujal. Newa 10(1):12-17

33- Fanous, N. E., A. A. Mohamed and Kh. A. Shaban (2017). Effect of Magnetic Treatment for Irrigation Ground Water on Soil Salinity, Nutrients, 
Water Productivity and Yield Fruit Trees at Sandy Soil. Egypt. J. Soil Sci. Vol. 57 No. 1, pp.113-123 http://dx.doi.org/10.21608/EJSS.2017.1528

34- Khoshravesh, M., S. M. J. Mirzaei., P. Shirazi, and R. N. Valashedi. (2018).

Evaluation of dripper clogging using magnetic water in drip irrigation. Applied Water Science 8:81 https://doi.org/10.1007/s13201-018-0725-7

35- Mostafa, H. (2020). Influence of magnetised irrigation water on the fertigation process and potato productivity Research in Agricultural Engineering, 66, 2020 (2): 43-51. https://doi.org/10.17221/1/2020-RAE.

36- Hilal, M. H., Y. M. El-Fakhrani, S. S. Mabrouk, A. I. Mohamed, and B. M. Ebead, (2013). Effect of magnetic treated irrigation water on salt removal from a sandy soil and on the availability of certain nutrients. Int. J. Eng. Appl. Sci. 2, 36-44.

37- Ali, Y. O., S. N. Rashidi and K. E. Fatatemeh, (2014). Applications of Magnetic Water Technology in Farming and Agriculture Development: A Review of Recent Advances. Current World Environment Vol. 9(3), 695-703.

38- Amer, M. M., A. G. El-Sanat and S. H. Rashed, (2014). Effects of magnetized low quality irrigation water on some soil properties and soybean yield (Glycine max L.) under salt affected soils conditions. J. Soil Sci. Agric. Eng., Mansoura Univ. 5, 1377-1388.

39- Zlotopolski. V. (2017). Magnetic Treatment Reduces Water Usage in Irrigation Without Negatively Impacting Yield, Photosynthesis and Nutrient Uptake in Lettuce. International Journal of Applied Agricultural Sciences 3 (5) :117-122 https://doi.org/10.11648/j.ijaas.20170305.13

40- Otsuka, I. and S. Ozeki, (2006). Does Magnetic Treatment of Water Change Its Properties, J. Phys. Chem. B, American Chemical Society. Vol. 110, No. 4, Pp. 1509-1512 https://doi.org/10.1021/jp056198x 